\title{
Restitution: A New Paradigm for Criminal Justice
}

Randy E. Barnett

Georgetown University Law Center, rb325@law.georgetown.edu

This paper can be downloaded free of charge from:

https://scholarship.law.georgetown.edu/facpub/1558

Randy E. Barnett, Restitution: A New Paradigm for Criminal Justice, 87 Ethics 279 (1977)

This open-access article is brought to you by the Georgetown Law Library. Posted with permission of the author. Follow this and additional works at: https://scholarship.law.georgetown.edu/facpub

Part of the Criminal Law Commons 


\title{
Restitution: A New Paradigm of Criminal Justice*
}

\author{
Randy E. Barnett
}

Harvard Law School

This paper will analyze the breakdown of our system of criminal justice in terms of what Thomas Kuhn would describe as a crisis of an old paradigm - punishment. I propose that this crisis could be solved by the adoption of a new paradigm of criminal justice-restitution. The approach will be mainly theoretical, though at various points in the discussion the practical implications of the rival paradigms will also be considered. A fundamental contention will be that many, if not most, of our system's ills stem from errors in the underlying paradigm. Any attempt to correct these symptomatic debilities without a reexamination of the theoretical underpinnings is doomed to frustration and failure. Kuhn's theories deal with the problems of science. What made his proposal so startling was its attempt to analogize scientific development to social and political development. Here, I will simply reverse the process by applying Kuhn's framework of scientific change to social, or in this case, legal development. ${ }^{1}$

*This paper was made possible by a research fellowship from the Law and Liberty Project of the Institute for Humane Studies, Menlo Park, California. A somewhat expanded version of it will appear in the book, Assessing the Criminal: Restitution, Retribution and the Legal Process, ed. Randy E. Barnett and John Hagel (Cambridge, Mass.: Ballinger Publishing Co., in press). Also, I wish to extend my appreciation to John V. Cody, Davis E. Keeler, Murray N. Rothbard, and Lloyd L. Weinreb for their invaluable criticism and comments. I am greatly in their debt and hope to be able at some future time to make suitable restitution.

1. What immediately follows is a brief outline of Kuhn's theory. Those interested in the defense of that theory should refer to his book, The Structure of Scientific Revolutions, 2d ed., enl. (Chicago: University of Chicago Press, 1970). A paradigm is an achievement in a particular discipline which defines the legitimate problems and methods of research within that discipline. This achievement is sufficiently unprecedented to attract new adherents away from rival approaches while providing many unsolved questions for these new practitioners to solve. As the paradigm develops and matures, it reveals occasional inabilities to solve new problems and explain new data. As attempts are made to make the facts fit the paradigm, the theoretical apparatus gradually becomes bulky and awkward, like Ptolemaic astronomy. Dissatisfaction with the paradigm begins to grow. Why not simply discard the paradigm and find another which better fits the facts? Unfortunately, this is an arduous process. All the great authorities and teachers were raised with the current paradigm and see the world through it. All the texts and institutions are committed to it. Radical alternatives hold promise but are so untested as to make wary all but the bold. The establishment is loath to abandon 
In the criminal justice system we are witnessing the death throes of an old and cumbersome paradigm, one that has dominated Western thought for more than 900 years. While this paper presents what is hoped to be a viable, though radical alternative, much would be accomplished by simply prompting the reader to reexamine the assumptions underlying the present system. Only if we are willing to look at our old problems in a new light do we stand a chance of solving them. This is our only hope, and our greatest challenge.

\section{THE CRISIS IN THE PARADIGM OF PUNISHMENT}

"Political revolutions are inaugurated by a growing sense, often restricted to a segment of the political community, that existing institutions have ceased adequately to meet the problems posed by an environment they have in part created. . . . In both political and scientific development the sense of malfunction that can lead to crisis is prerequisite to revolution." Kuhn's description of the preconditions for scientific and political revolutions could accurately describe the current state of the criminal law. However, simply to recognize the existence of a crisis is not enough. We must look for its causes. The Kuhnian methodology suggests that we critically examine the paradigm of punishment itself.

The problems which the paradigm of punishment is supposed to solve are many and varied. A whole literature on the philosophy of punishment has arisen in an effort to justify or reject the institution of punishment. For our purposes the following definition from the Encyclopedia of Philosophy should suffice: "Characteristically punishment is unpleasant. It is inflicted on an offender because of an offense he has committed; it is deliberately imposed, not just the natural consequence of a person's action (like a hangover), and the unpleasantness is essential to it, not an accompaniment to some other treatment (like the pain of the dentist's drill)."

Two types of arguments are commonly made in defense of punishment. The first is that punishment is an appropriate means to some justifiable end such as, for example, deterrence of crime. The second type of argument is that punishment is justified as an end in itself. On this view, whatever ill effects it might engender, punishment for its own sake is good.

The first type of argument might be called the political justification of

its broad and intricate theory in favor of a new and largely unknown hypothesis. Gradually, however, as the authorities die off and the problems with the old paradigm increase, the "young turks" get a better hearing in both the journals and the classroom. In a remarkably rapid fashion, the old paradigm is discarded for the new. Anyone who still clings to it is now considered to be antiquated or eccentric and is simply read out of the profession. All research centers on the application of the new paradigm. Kuhn characterizes this overthrow of one paradigm by another as a revolution.

2. Ibid., p. 92.

3. Stanley I. Benn, "Punishment," in The Encyclopedia of Philosophy, ed. Paul Edwards (New York: Macmillan Publishing Co., 1967), 7:29 (emphasis added). 
punishment, for the end which justifies its use is one which a political order is presumably dedicated to serve: the maintenance of peaceful interactions between individuals and groups in a society. There are at least three ways that deliberate infliction of harm on an offender is said to be politically justified.

- 1. One motive for punishment, especially capital punishment and imprisonment, is the "intention to deprive offenders of the power of doing future mischief." Although it is true that an offender cannot continue to harm society while incarcerated, a strategy of punishment based on disablement has several drawbacks.

Imprisonment is enormously expensive. This means that a double burden is placed on the innocent who must suffer the crime and, in addition, pay through taxation for the support of the offender and his family if they are forced onto welfare. Also, any benefit of imprisonment is temporary; eventually, most offenders will be released. If their outlook has not improved - and especially if it has worsened - the benefits of incarceration are obviously limited. Finally, when disablement is permanent, as with capital punishment or psychosurgery, it is this very permanence, in light of the possibility of error, which is frightening. For these reasons, "where disablement enters as an element into penal theories, it occupies, as a rule, a subordinate place and is looked upon as an object subsidiary to some other end which is regarded as paramount. . .."

2. Rehabilitiation of a criminal means a change in his mental babitus so that he will not offend again. It is unclear whether the so-called treatment model which views criminals as a doctor would view a patient is truly a "retributive" concept. Certainly it does not conform to the above definition characterizing punishment as deliberately and essentially unpleasant. It is an open question whether any end justifies the intentional, forceful manipulation of an individual's thought processes by anyone, much less the state. To say that an otherwise just system has incidentally rehabilitative effects which may be desirable is one thing, but it is quite another to argue that these effects themselves justify the system. The horrors to which such reasoning can lead are obvious from abundant examples in history and contemporary society. ${ }^{6}$

Rehabilitation as a reaction against the punishment paradigm will be considered below, but one aspect is particularly relevant to punishment as defined here. On this view, the visiting of unpleasantness itself will cause the offender to see the error of his ways; by having "justice" done him, the criminal will come to appreciate his error and will change his moral outlook. This end, best labeled "reformation," is speculative at best and counterfactual at worst. On the contrary, "it has been observed that, as a rule

4. Heinrich Oppenheimer, The Rationale of Punishment (London: University of London Press, 1913), p. 255.

5. Ibid.

6. See Thomas Szasz, Law, Liberty, and Psychiatry (New York: Macmillan Co., 1963). 
. . . ruthless punishments, far from mollifying men's ways, corrupt them and stir them to violence."

3. The final justification to be treated here-deterrence-actually has two aspects. The first is the deterrent effect that past demonstrations of punishment have on the future conduct of others; the second is the effect that threats of future punishment have on the conduct of others. The distinction assumes importance when some advocates argue that future threats lose their deterrent effect when there is a lack of past demonstrations. Past punishment, then, serves as an educational tool. It is a substitute for or reinforcement of threats of future punishment.

As with the goals mentioned above, the empirical question of whether punishment has this effect is a disputed one. ${ }^{8}$ I shall not attempt to resolve this question here, but will assume arguendo that punishment even as presently administered has some deterrent effect. It is the moral question which is disturbing. Can an argument from deterrence alone "justify" in any sense the infliction of pain on a criminal? It is particularly disquieting that the actual levying of punishment is done not for the criminal himself, but for the educational impact it will have on the community. The criminal act becomes the occasion of, but not the reason for, the punishment. In this way, the actual crime becomes little more than an excuse for punishing.

Surely this distorts the proper functioning of the judicial process. For if deterrence is the end it is unimportant whether the individual actually committed the crime. Since the public's perception of guilt is the prerequisite of the deterrent effect, all that is required for deterrence is that the individual is "proved" to have committed the crime. The actual occurrence would have no relevance except insofar as a truly guilty person is easier to prove guilty. The judicial process becomes, not a truth-seeking device, but solely a means to legitimate the use of force. To treat criminals as means to the ends of others in this way raises serious moral problems. This is not to argue that men may never use others as means but rather to question the use of force against the individual because of the effect such use will have on others. It was this that concerned del Vecchio when he stated that "the human person always bears in himself something sacred, and it is therefore not permissable to treat him merely as a means towards an end ouside of himself."

Finally, deterrence as the ultimate justification of punishment cannot rationally limit its use. It "provides no guidance until we're told how much commission of it is to be deterred."10 Since there are always some who commit crimes, one can always argue for more punishment. Robert Nozick points out that there must be criteria by which one decides how much

7. Giorgio del Vecchio, "The Struggle against Crime," in The Philosophy of Punishment, ed. H. B. Acton (London: Macmillan Co., 1969), p. 199.

8. See, e.g., Samuel Yochelson and Stanton E. Samenow, The Criminal Personality, vol. 1, A Profile for Change (New York: Jason Aronson, Inc., 1976), pp. 411-16.

9. Del Vecchio, p. 199.

10. Robert Nozick, Anarchy, State, and Utopia (New York: Basic Books, 1974), p. 61. 
deterrence may be inflicted. ${ }^{11}$ One is forced therefore to employ "higher" principles to evaluate the legitimacy of punishment.

It is not my thesis that deterrence, reformation, and disablement are undesirable goals. On the contrary, any criminal justice system should be critically examined to see if it is having these and other beneficial effects. The view advanced here is simply that these utilitarian benefits must be incidental to a just system; they cannot, alone or in combination, justify a criminal justice system. Something more is needed. There is another more antiquated strain of punishment theory which seeks to address this problem. The moral justifications of punishment view punishment as an end in itself. This approach has taken many forms. ${ }^{12}$ On this view, whatever ill or beneficial results it might have, punishment of lawbreakers is good for its own sake. This proposition can be analyzed on several levels.

The most basic question is the truth of the claim itself. Some have argued that "the alleged absolute justice of repaying evil with evil (maintained by Kant and many other writers) is really an empty sophism. If we go back to the Christian moralists, we find that an evil is to be put right only by doing good." 13 This question is beyond the scope of this treatment. The subject has been extensively dealt with by those more knowledgeable than $I^{14}$ The more relevant question is what such a view of punishment as a good can be said to imply for a system of criminal justice. Even assuming that it would be good if, in the nature of things, the wicked got their "come-uppance," what behavior does this moral fact justify? Does it justify the victim authoring the punishment of his offender? Does it justify the same action by the victim's family, his friends, his neighbors, the state? If so what punishment should be imposed and who should decide?

It might be argued that the natural punishment for the violation of natural rights is the deserved hatred and scorn of the community, the resultant ostracism, and the existential hell of being an evil person. The question then is not whether we have the right to inflict some "harm" or unpleasantness on a morally contemptible person-surely, we do; the question is not whether such a punishment is "good"-arguably, it is. The issue is whether the "virtue of some punishment" justifies the forceful imposition of unpleasantness on a rights violator as distinguished from the morally imperfect. Any moral theory of punishment must recognize and deal with this distinction. Finally, it must be established that the state is the legitimate author of punishment, a proposition which further assumes the moral and legal legitimacy of the state. To raise these issues is not to resolve them, but it would seem that the burden of proof is on those seeking to justify the use of force against the individual. Suffice it to say that I am

11. Ibid., pp. 59-63.

12. For a concise summary, see Oppenheimer, p. 31.

13. Del Vecchio, p. 198.

14. See, e.g., Walter Kaufmann, Without Guilt and Justice (New York: Peter H. Wyden, Inc., 1973), esp. chap. 2. 
skeptical of finding any theory which justifies the deliberate, forceful imposition of punishment within or without a system of criminal justice.

The final consideration in dealing with punishment as an end in itself is the possibility that the current crisis in the criminal justice system is in fact a crisis of the paradigm of punishment. While this, if true, does not resolve the philosophical issues, it does cast doubt on the punishment paradigm's vitality as the motive force behind a system of criminal justice. Many advocates of punishment argue that its apparent practical failings exist because we are not punishing enough. All that is needed, they say, is a crackdown on criminals and those victims and witnesses who shun participation in the criminal justice system; the only problem with the paradigm of punishment is that we are not following it. ${ }^{15}$ This response fails to consider why the system doggedly refuses to punish to the degree required to yield beneficial results and instead punishes in such a way as to yield harmful results. The answer may be that the paradigm of punishment is in eclipse, that the public lacks the requisite will to apply it in anything but the prevailing way.

Punishment, particularly state punishment is the descendant of the tradition which imparts religious and moral authority to the sovereign and, through him, the community. Such an authority is increasingly less credible in a secular world such as ours. Today there is an increasing desire to allow each individual to govern his own life as he sees fit provided he does not violate the rights of others. This desire is exemplified by current attitudes toward drug use, abortion, and pornography. Few argue that these things are good. It is only said that where there is no victim the state or community has no business meddling in the peaceful behavior of its citizens, however morally suspect it may be. ${ }^{16}$

Furthermore, if the paradigm of punishment is in a "crisis period" it is as much because of its practical drawbacks as the uncertainty of its moral status. The infliction of suffering on a criminal tends to cause a general feeling of sympathy for him. There is no rational connection between a term of imprisonment and the harm caused the victim. Since the prison term is supposed to be unpleasant, at least a part of the public comes to see the criminal as a victim, and the lack of rationality also causes the offender to feel victimized. This reaction is magnified by the knowledge that most crimes go unpunished and that even if the offender is caught the judicial process is long, arduous, and far removed from the criminal act. While this is obvious to most, it is perhaps less obvious that the punishment paradigm is largely at fault. The slow, ponderous nature of our system of justice is largely due to a fear of an unjust infliction of punishment on the innocent (or even the guilty). The more awful the sanction, the more elaborate need

15. See, e.g., "Crime: A Case for More Punishment," Business Week (September 15, 1975), pp. $92-97$.

16. This problem is examined, though not ultimately resolved, by Edwin M. Schur in his book Crimes without Victims-Deviant Behavior and Public Policy, Abortion, Homosexuality, and Drug Addiction (Englewood Cliffs, N.J.: Prentice-Hall, Inc., 1965). 
be the safeguards. The more the system is perceived as arbitrary and unfair, the more incentive there is for defendants and their counsel to thwart the truth-finding process. Acquittal becomes desirable at all costs. As the punitive aspect of a sanction is diminished, so too would be the perceived need for procedural protections.

A system of punishment, furthermore, offers no incentive for the victim to involve himself in the criminal justice process other than to satisfy his feelings of duty or revenge. The victim stands to gain little if at all by the conviction and punishment of the person who caused his loss. This is true even of those systems discussed below which despense state compensation based on the victim's need. The system of justice itself imposes uncompensated costs by requiring a further loss of time and money by the victim and witnesses and by increasing the perceived risk of retaliation.

Finally, punishment which seeks to change an offender's moral outlook, or at least to scare him, can do nothing to provide him with the skills needed to survive in the outside world. In prison, he learns the advanced state of the criminal arts and vows not to repeat the mistake that led to his capture. The convict emerges better trained and highly motivated to continue a criminal career.

The crisis of the paradigm of punishment has at its roots the collapse of its twin pillars of support: its moral legitimacy and its practical efficacy. As Kaufmann concludes, "the faith in retributive justice is all but dead."

\section{ATTEMPTS TO SALVAGE THE PARADIGM OF PUNISHMENT}

"All crises begin with the blurring of a paradigm and the consequent loosening of the rules for normal research." is presented, authorities will cling to the old one, either ignoring the problem or salvaging the paradigm with ad hoc explanations and solutions. Why are paradigms never rejected outright? Why must there always be a new paradigm before the old one is abandoned? Kuhn does not explicitly discuss this, but R. A. Childs hypothesizes "that, as such, paradigms may serve the function of increasing man's sense of control over some aspect of reality, or some aspect of his own life. If this is so, then we would expect that a straightforward abandonment of a paradigm would threaten that sense of control."'19

This psychological need for an explanation may in turn explain the many efforts to shore up the paradigm of punishment. The three attempts to be examined next have at their roots a perception of its fundamental errors, and at the same time they highlight three goals of any new paradigm of criminal justice.

1. Proportionate punishment. The king abandoned the composition

17. Kaufmann, p. 46.

18. Kuhn, p. 82.

19. R. A. Childs, "Liberty and the Paradigm of Statism," in The Libertarian Alternative, ed. Tibor Machan (Chicago: Nelson-Hall Co., 1974), p. 505. 
system $^{20}$ for the system of punishment because punishment struck terror in the hearts of the people, and this served to inspire awe for the power of the king and state. But there was no rational connection between the seriousness of the crime and the gravity of the punishment and, therefore, no limit to the severity of punishment. Hideous tortures came to be employed: "But some of the men of the Enlightenment sought to counter the inhumanity of their Christian predecessors with appeals to reason. They thought that retributive justice had a mathematical quality and that murder called for capital punishment in much the same way in which two plus two equals four." 21

The appeal to proportionality was one of the early attempts to come to grips with deficiencies in the paradigm of punishment. It was doomed to failure, for there is no objective standard by which punishments can be proportioned to fit the crime. Punishment is incommensurate with crime. This solution is purely ad hoc and intuitive. We shall, however, find the goal of proportionate sentencing useful in the formation of a new paradigm.

2. Rehabilitation. It was noted earlier that the infliction of punishment tends to focus attention on the plight of the criminal. Possibly for this reason, the next humanitarian trend was to explore the proper treatment of criminals. Punishment failed to reform the criminal, and this led observers to inquire how the situation might be improved. Some felt that the sole end of the penal system was rehabilitation, so attention was turned to modifying the criminal's behavior (an obviously manipulative end). Emphasis was placed on education, job training, and discipline.

Unfortunately, the paradigm of punishment and the political realities of penal administration have all but won out. There is simply no incentive for prison authorities to educate and train. Their job is essentially political. They are judged by their ability to keep the prisoners within the walls and to keep incidents of violence within the prison to a minimum; as a result, discipline is the main concern. Furthermore, since he is sentenced to a fixed number of years (less time off for good behavior-so-called good time), there is no institutional incentive for the prisoner to improve himself apart from sheer boredom. Productive labor in prison is virtually nonexistent, with only obsolete equipment, if any, available. Except perhaps for license plates and other state needs, the prisoners produce nothing of value; the prisons make no profit and the workers are paid, if at all, far below market wages. They are unable to support themselves or their families. The state, meaning the innocent taxpayer, supports the prisoner, and frequently the families as well via welfare.

20. Composition was the medieval version of a restitutionary system. For a fascinating outline of how such a system operated and how it came to be supplanted by state-authored punishment, see Stephen Schafer, Compensation and Restitution to Victims of Crime, 2d ed., enl. (Montclair, N.J.: Patterson Smith Publishing Corp., 1970); Richard E. Laster, "Criminal Restitution: A Survey of Its Past History and an Analysis of Its Present Usefulness," University of Richmond Law Review S (1970): 71-80; L. T. Hobhouse, Morals in Evolution (London: Chapman \& Hall, 1951).

21. Kaufmann, p. 45. 
Rehabilitation has been a long-time goal of the penal system, but the political nature of government-run prisons and the dominance of the paradigm of punishment has inevitably prevented its achievement. Prisons remain detention centers, all too temporarily preventing crime by physically confining the criminals.

3. Victim compensation. It is natural that the brutalities resulting from the paradigm of punishment would get first attention from humanitarians and that the persons subjected to those practices would be next. Until recently, the victim of crime was the forgotten party. Within the last few years a whole new field has opened up called victimology. ${ }^{22}$ With it has come a variety of proposals, justifications, and statutes. ${ }^{23}$

Certain features are common to virtually every compensation proposal: (a) Compensation for crimes would be dispensed by the state from tax revenue. (b) Compensation is "a matter of grace" rather than an assumption by the state of legal responsibility for the criminal loss suffered by the victim. (c) Most proposals allow for aid only on a "need" or "hardship" basis. (d) Most are limited to some sort of crime of violence or the threat of force or violence. $(e)$ None questions the paradigm of punishment.

The goal of these proposals and statutes is laudable. The victim is the forgotten man of crime. But the means proposed is the same tired formula: welfare to those in "need." In short, the innocent taxpayer repays the innocent victim (if the victim can prove he "needs" help) while the guilty offender is subjected to the sanction of punishment with all its failings. Like proportionate punishment and rehabilitation, the goal of victim compensation is a recognition of very real problems in our criminal justice system, and at the same time it ignores the source of these problems: our conception of crime as an offense against the state whose proper sanction is punishment. Until a viable, new paradigm is presented, ad boc solutions like the ones discussed here are all that can be hoped for. And it is a vain hope indeed, for they attack the symptoms while neglecting the causes of the problem. What is needed is a new paradigm.

\section{OUTLINE OF A NEW PARADIGM}

The idea of restitution is actually quite simple. It views crime as an offense by one individual against the rights of another. The victim has suffered a loss. Justice consists of the culpable offender making good the loss he has caused. It calls for a complete refocusing of our image of crime. Kuhn would call it a "shift of world-view." Where we once saw an offense against society, we now see an offense against an individual victim. In a

22. For a brief definition of "victimology," see Emilo C. Viano, "Victimology: The Study of the Victim," Victimology 1 (1976): 1-7. For an extensive collection of papers on various aspects of victimology, see Emilo C. Viano, ed., Victims and Society (Washington, D.C.: Visage Press, 1976).

23. For a discussion and list of symposiums, journal articles, and statutes concerning victim compensation, see Steven Schafer, pp. 139-57, and appendix; see also Joe Hudson and Burt Galaway, eds., Considering the Victim: Readings in Restitution and Victim Compensation (Springfield, Ill.: Charles C. Thomas, 1975), esp. pp. 361-436. 
way, it is a common sense view of crime. The armed robber did not rob society; he robbed the victim. His debt, therefore, is not to society; it is to the victim. There are really two types of restitution proposals: a system of "punitive" restitution and a "pure" restitutional system.

1. Punitive restitution. "Since rehabilitation was admitted to the aims of penal law two centuries ago, the number of penological aims has remained virtually constant. Restitution is waiting to come in." ${ }^{24}$ Given this view, restitution should merely be added to the paradigm of punishment. Stephen Schafer outlines the proposal: "[Punitive] restitution, like punishment, must always be the subject of judicial consideration. Without exception it must be carried out by personal performance by the wrong-doer, and should even then be equally burdensome and just for all criminals, irrespective of their means, whether they be millionaires or labourers." ${ }^{25}$

There are many ways by which such a goal might be reached. The offender might be forced to compensate the victim by his own work, either in prison or out. If it came out of his pocket or from the sale of his property this would compensate the victim, but it would not be sufficiently unpleasant for the offender. Another proposal would be that the fines be proportionate to the earning power of the criminal. Thus, "A poor man would pay in days of work, a rich man by an equal number of days' income or salary." ${ }^{26}$ Herbert Spencer made a proposal along similar lines in his excellent "Prison-Ethics," which is well worth examining. ${ }^{27}$ Murray N. Rothbard and others have proposed a system of "double payments" in cases of criminal behavior ${ }^{28}$ While closer to pure restitution than other proposals, the "double damages" concept preserves a punitive aspect.

Punitive restitution is an attempt to gain the benefits of pure restitution, which will be considered shortly, while retaining the perceived advantages of the paradigm of punishment. Thus, the prisoner is still "sentenced" to some unpleasantness-prison labor or loss of $X$ number of days' income. That the intention is to preserve the "hurt" is indicated by the hesitation to accept an out-of-pocket payment or sale of assets. This is considered too "easy" for the criminal and takes none of his time. The amount of payment is determined not by the actual harm but by the ability of the offender to pay. Of course, by retaining the paradigm of punishment this proposal involves many of the problems we raised earlier. In this sense it can be considered another attempt to salvage the old paradigm.

2. Pure restitution. "Recompense or restitution is scarcely a punishment as long as it is merely a matter of returning stolen goods or money. . . .

24. Gerhard O. W. Mueller, "Compensation for Victims of Crime: Thought before Action," Minnesota Law Review 50 (1965): 221.

25. Schafer, p. 127.

26. Ibid.

27. Herbert Spencer, "Prison-Ethics," in Essays: Scientific, Political and Speculative (New York: D. Appleton \& Co., 1907), 3:152-91.

28. Murray N. Rothbard, Libertarian Forum 14, no. 1 (January 1972): 7-8. 
The point is not that the offender deserves to suffer; it is rather that the offended party desires compensation." ${ }^{29}$ This represents the complete overthrow of the paradigm of punishment. No longer would the deterrence, reformation, disablement, or rehabilitation of the criminal be the guiding principle of the judicial system. The attainment of these goals would be incidental to, and as a result of, reparations paid to the victim. No longer would the criminal deliberately be made to suffer for his mistake. Making good that mistake is all that would be required. What follows is a possible scenario of such a system.

When a crime occurred and a suspect was apprehended, a trial court would attempt to determine his guilt or innocence. If found guilty, the criminal would be sentenced to make restitution to the victim. ${ }^{30}$ If a criminal is able to make restitution immediately, he may do so. This would discharge his liability. If he were unable to make restitution, but were found by the court to be trustworthy, he would be permitted to remain at his job (or find a new one) while paying restitution out of his future wages. This would entail a legal claim against future wages. Failure to pay could result in garnishment or a new type of confinement.

If it is found that the criminal is not trustworthy, or that he is unable to gain employment, he would be confined to an employment project. ${ }^{31}$ This would be an industrial enterprise, preferably run by a private concern, which would produce actual goods or services. The level of security at each employment project would vary according to the behavior of the offenders. Since the costs would be lower, inmates at a lower-security project would receive higher wages. There is no reason why many workers could not be permitted to live with their families inside or outside the facility, depending, again, on the trustworthiness of the offender. Room and board would be deducted from the wages first, then a certain amount for restitution. Anything over that amount the worker could keep or apply toward further restitution, thus hastening his release. If a worker refused to work, he would be unable to pay for his maintenance, and therefore would not in principle be entitled to it. If he did not make restitution he could not be released. The exact arrangement which would best provide for high productivity, minimal security, and maximum incentive to work and repay the victim cannot be determined in advance. Experience is bound to yield some

29. Kaufmann, p. 55.

30. The nature of judicial procedure best designed to carry out this task must be determined. For a brief discussion of some relevant considerations, see Laster, pp. 80-98; Burt Galaway and Joe Hudson, "Issues in the Correctional Implementation of Restitution to Victims of Crime," in Considering the Victim, pp. 351-60. Also to be dealt with is the proper standard of compensation. At least initially, the problem of how much payment constitutes restitution would be no different than similar considerations in tort law. This will be considered at greater length below.

31. Such a plan (with some significant differences) has been suggested by Kathleen J. Smith in A Cure for Crime: The Case for the Self-determinate Prison Sentence (London: Gerald, Duckworth \& Co., 1965), pp. 13-29; see also Morris and Linda Tannehill, The Market for Liberty (Lansing, Mich.: Privately printed, 1970), pp. 44-108. 
plans superior to others. In fact, the experimentation has already begun. ${ }^{32}$ While this might be the basic system, all sorts of refinements are conceivable, and certainly many more will be invented as needs arise. A few examples might be illuminating. With such a system of repayment, victim crime insurance would be more economically feasible than at present and highly desirable. The cost of awards would be offset by the insurance company's right to restitution in place of the victim (right of subrogation). The insurance company would be better suited to supervise the offender and mark his progress than would the victim. To obtain an earlier recovery, it could be expected to innovate so as to enable the worker to repay more quickly (and, as a result, be released that much sooner). The insurance companies might even underwrite the employment projects themselves as well as related industries which would employ the skilled worker after his release. Any successful effort on their part to reduce crime and recidivism would result in fewer claims and lower premiums. The benefit of this insurance scheme for the victim is immediate compensation, conditional on the victim's continued cooperation with the authorities for the arrest and conviction of the suspect. In addition, the centralization of victim claims would, arguably, lead to efficiencies which would permit the pooling of small claims against a common offender.

Another highly useful refinement would be direct arbitration between victim and criminal. This would serve as a sort of healthy substitute for plea bargaining. By allowing the guilty criminal to negotiate a reduced payment in return for a guily plea, the victim (or his insurance company) would be saved the risk of an adverse finding at trial and any possible additional expense that might result. This would also allow an indigent criminal to substitute personal services for monetary payments if all parties agreed.

Arbitration is argued for by John M. Greacen, deputy director of the National Institute for Law Enforcement and Criminal Justice. He sees the possible advantages of such reform as the ". . . development of more creative dispositions for most criminal cases; for criminal victims the increased use of restitution, the knowledge that their interests were considered in the criminal process; and an increased satisfaction with the outcome; increased awareness in the part of the offender that his crime was committed against another human being, and not against society in general; increased possibility that the criminal process will cause the offender to acknowledge responsibility for his acts." ${ }^{\prime 3}$ Greacen notes several places

32. For a recent summary report, see Burt Galaway, "Restitution as an Integrative Punishment" (paper prepared for the Symposium on Crime and Punishment: Restitution, Retribution, and Law, Harvard Law School, March 1977).

33. John M. Greacen, "Arbitration: A Tool for Criminal Cases?” Barrister (Winter 1975), p. 53; see also Galaway and Hudson, pp. 352-55; "Conclusions and Recommendations, International Study Institute on Victimology, Bellagio, Italy, July 1-12, 1975," Victimology 1 (1976): 150-51; Ronald Goldfarb, Jails: The Ultimate Ghetto (Garden City, N.Y.: Anchor Press/Doubleday, 1976), p. 480 . 
where such a system has been tried with great success, most notably Tucson, Arizona, and Columbus, Ohio. ${ }^{34}$

Something analogous to the medieval Irish system of sureties might be employed as well. ${ }^{35}$ Such a system would allow a concerned person, group, or company to make restitution (provided the offender agrees to this). The worker might then be released in the custody of the surety. If the surety had made restitution, the offender would owe restitution to the surety who might enforce the whole claim or show mercy. Of course, the more violent and unreliable the offender, the more serious and costly the offense, the less likely it would be that anyone would take the risk. But for first offenders, good workers, or others that charitable interests found deserving (or perhaps unjustly convicted) this would provide an avenue of respite.

\section{RESTITUTION AND RIGHTS}

These three possible refinements clearly illustrate the flexibility of a restitutional system. It may be less apparent that this flexibility is inherent to the restitutional paradigm. Restitution recognizes rights in the victim, and this is a principal source of its strength. The nature and limit of the victim's right to restitution at the same time defines the nature and limit of the criminal liability. In this way, the aggressive action of the criminal creates a debt to the victim. The recognition of rights and obligations make possible many innovative arrangements. Subrogation, arbitration, and suretyship are three examples mentioned above. They are possible because this right to compensation ${ }^{36}$ is considered the property of the victim and can therefore be delegated, assigned, inherited, or bestowed. One could determine in advance who would acquire the right to any restitution which he himself might be unable to collect.

The natural owner of an unenforced death claim would be an insurance company that had insured the deceased. The suggestion has been made that a person might thus increase his personal safety by insuring with a company well known for tracking down those who injure its policy holders. In fact, the partial purpose of some insurance schemes might be to provide the funds with which to track down the malefactor. The insurance company, having paid the beneficiaries would "stand in their shoes." It would remain possible, of course, to simply assign or devise the right directly to the beneficiaries, but this would put the burden of enforcement on persons likely to be unsuited to the task.

If one accepts the Lockean trichotomy of property ownership, ${ }^{37}$ that is, acquiring property via exchange, gifts, and homesteading (mixing one's labor

34. Greacen, p. 53.

35. For a description of the Irish system, see Joseph R. Peden, "Property Rights in Medieval Ireland: Celtic Law versus Church and State" (paper presented at the Symposium on the Origins and Development of Property Rights, University of San Francisco, January 1973); for a theoretical discussion of a similar proposal, see Spencer, pp. 182-86.

36. Or, perhaps more accurately, the compensation itself.

37. For a brief explanation of this concept and several of its possible applications, see Murray 
with previously unowned land or objects), the possibility arises that upon a person's wrongful death, in the absence of any heirs or assignees, his right to compensation becomes unowned property. The right could then be claimed (homesteaded) by anyone willing to go to the trouble of catching and prosecuting the criminal. Firms might specialize in this sort of activity, or large insurance companies might make the effort as a kind of "loss leader" for public relations purposes.

This does, however, lead to a potentially serious problem with the restitutional paradigm: what exactly constitutes "restitution"? What is the standard by which compensation is to be made? Earlier we asserted that any such problem facing the restitutional paradigm faces civil damage suits as well. The method by which this problem is dealt with in civil cases could be applied to restitution cases. But while this is certainly true, it may be that this problem has not been adequately handled in civil damage suits either.

Restitution in cases of crimes against property is a manageable problem. Modern contract and tort doctrines of restitution are adequate. The difficulty lies in cases of personal injury or death. How can you put a price on life or limb, pain or suffering? Is not any attempt to do so of necessity arbitrary? It must be admitted that a fully satisfactory solution to this problem is lacking, but it should also be stressed that this dilemna, though serious, has little impact on the bulk of our case in favor of a restitutional paradigm. It is possible that no paradigm of criminal justice can solve every problem, yet the restitutional approach remains far superior to the paradigm of punishment or any other conceivable rival.

This difficulty arises because certain property is unique and irreplaceable. As a result, it is impossible to approximate a "market" or "exchange" value expressed in monetary terms. Just as there is no rational relationship between a wrongfully taken life and ten years in prison, there is little relationship between that same life and $\$ 20,000$. Still, the nature of this possibly insoluble puzzle reveals a restitutional approach theoretically superior to punishment. For it must be acknowledged that a real, tangible loss bas occurred. The problem is only one of incommensurability. Restitution provides some tangible, albeit inadequate, compensation for personal injury. Punishment provides none at all. ${ }^{38}$

It might be objected that to establish some "pay scale" for personal injury is not only somewhat arbitrary but also a disguised reimplementation of punishment. Unable to accept the inevitable consequences of restitutional punishment, the argument continues, I have retreated to a pseudorestitutional award. Such a criticism is unfair. The true test in this instance is one of primacy of intentions. Is the purpose of a system to compensate victims

N. Rothbard, "Justice and Property Rights," in Property in a Humane Economy, ed. Samuel L. Blumenfeld (La Salle, Ill.: Open Court Publishing Co., 1974), pp. 101-22.

38. That the "spiritual" satisfaction which punishment may or may not provide is to be recognized as a legitimate form of "compensation" is a claim retributionists must defend. 
for their losses (and perhaps, as a consequence, punish the criminals), or is its purpose to punish the criminals (and perhaps, as a consequence, compensate the victims for their losses)? The true ends of a criminal justice system will determine its nature. In short, arbitrariness alone does not imply a retributive motive. And while arbitrariness remains to some extent a problem for the restitutional paradigm, it is less of a problem for restitution than for punishment, since compensation has some rational relationship to damages and costs.

\section{ADVANTAGES OF A RESTITUTIONAL SYSTEM}

1. The first and most obvious advantage is the assistance provided to victims of crime. They may have suffered an emotional, physical, or financial loss. Restitution would not change the fact that a possibly traumatic crime has occurred (just as the award of damages does not undo tortious conduct). Restitution, however, would make the resulting loss easier to bear for both victims and their families. At the same time, restitution would avoid a major pitfall of victim compensation/welfare plans: Since it is the criminal who must pay, the possibility of collusion between victim and criminal to collect "damages" from the state would be all but eliminated.

2. The possibility of receiving compensation would encourage victims to report crimes and to appear at trial. This is particularly true if there were a crime insurance scheme which contractually committed the policyholder to testify as a condition for payment, thus rendering unnecessary oppressive and potentially tyrannical subpoenas and contempt citations. Even the actual reporting of the crime to police is likely to be a prerequisite for compensation. Such a requirement in auto theft insurance policies has made car thefts the most fully reported crime in the Unites States. Furthermore, insurance companies which paid the claim would have a strong incentive to see that the criminal was apprehended and convicted. Their pressure and assistance would make the proper functioning of law enforcement officials all the more likely.

3. Psychologist Albert Eglash has long argued that restitution would aid in the rehabilitation of criminals. "Restitution is something an inmate does, not something done for or to him. . . . Being reparative, restitution can alleviate guilt and anxiety, which can otherwise precipitate further offenses." ${ }^{39}$ Restitution, says Eglash, is an active effortful role on the part of the offender. It is socially constructive, thereby contributing to the offender's self-esteem. It is related to the offense and may thereby redirect the thoughts which motivated the offense. It is reparative, restorative, and may actually leave the situation better than it was before the crime, both for the criminal and victim. ${ }^{40}$

39. Albert Eglash, "Creative Restitution: Some Suggestions for Prison Rehabilitation Programs," American Journal of Correction 40 (November-December 1958): 20.

40. Ibid.; see $a \rightarrow$ Eglash's "Creative Restitution: A Broader Meaning for an Old Term," Journal of Criminal Law and Criminology 48 (1958): 619-22; Burt Galaway and Joe Hudson, "Restitu- 
4. This is a genuinely "self-determinative" sentence. ${ }^{41}$ The worker would know that the length of his confinement was in his own hands. The harder he worked, the faster he would make restitution. He would be the master of his fate and would have to face that responsibility. This would encourage useful, productive activity and instill a conception of reward for good behavior and hard work. Compare this with the current probationary system and "indeterminate sentencing" where the decision for release is made by the prison bureaucracy, based only (if fairly administered) on "good behavior"; that is, passive acquiescence to prison discipline. Also, the fact that the worker would be acquiring marketable skills rather than more skillful methods of crime should help to reduce the shocking rate of recidivism.

5. The savings to taxpayers would be enormous. No longer would the innocent taxpayer pay for the apprehension and internment of the guilty. The cost of arrest, trial, and internment would be borne by the criminal himself. In addition, since now-idle inmates would become productive workers (able, perhaps, to support their families), the entire economy would benefit from the increase in overall production. ${ }^{42}$

6. Crime would no longer pay. Criminals, particularly shrewd whitecollar criminals, would know that they could not dispose of the proceeds of their crime and, if caught, simply serve time. They would have to make full restitution plus enforcement and legal costs, thereby greatly increasing the incentive to prosecute. While this would not eliminate such crime it would make it rougher on certain types of criminals, like bank and corporation officials, who harm many by their acts with a virtual assurance of lenient legal sanctions. ${ }^{43}$ It might also encourage such criminals to keep the money around for a while so that, if caught, they could repay more easily. This would make a full recovery more likely.

A restitutional system of justice would benefit the victim, the criminal, and the taxpayer. The humanitarian goals of proportionate punishment, rehabilitation, and victim compensation are dealt with on a fundamental level making their achievement more likely. In short, the paradigm of restitution would benefit all but the entrenched penal bureaucracy and enhance justice at the same time. What then is there to stop us from overthrowing the paradigm of punishment and its penal system and putting in its place this more efficient, more humane, and more just system? The proponents of punishment and others have a few powerful counterarguments. It is to these we now turn.

\footnotetext{
tion and Rehabilitation-Some Central Issues," Crime and Delinquency 18 (1972): 403-10.

41. Smith, pp. 13-29.

42. An economist who favors restitution on efficiency grounds is Gary S. Becker, although he does not break with the paradigm of punishment. Those interested in a mathematical "cost-benefit" analysis should see his "Crime and Punishment," Journal of Political Economy 76 (1968): 169-217.

43. This point is also made by Minocher Jehangirji Sethna in his paper, "Treatment and Atonement for Crime," in Victims and Society, p. 538.
} 


\section{OBJECTIONS TO RESTITUTION}

1. Practical criticisms of restitution. It might be objected that "crimes disturb and offend not only those who are directly their victim, but also the whole social order." ${ }^{\prime 44}$ Because of this, society, that is, individuals other than the victim, deserves some satisfaction from the offender. Restitution, it is argued, will not satisfy the lust for revenge felt by the victim or the "community's sense of justice." This criticism appears to be overdrawn. Today most members of the community are mere spectators of the criminal justice system, and this is largely true even of the victim. ${ }^{45}$ One major reform being urged presently is more victim involvement in the criminal justice process. ${ }^{46}$ The restitution proposal would necessitate this involvement. And while the public generally takes the view that officials should be tougher on criminals, with "tougher" taken by nearly everyone to mean more severe in punishing, one must view this "social fact" in light of the lack of a known alternative. The real test of public sympathies would be to see which sanction people would choose: incarceration of the criminal for a given number of years or the criminal's being compelled to make restitution to the victim: While the public's choice is not clearly predictable, neither can it be assumed that it would reject restitution. There is some evidence to the contrary. ${ }^{47}$

44. Del Vecchio, p. 198.

45. William F. McDonald, "Towards a Bicentennial Revolution in Criminal Justice: The Return of the Victim," American Criminal Law Review 13 (1976): 659; see also his paper "Notes on the Victim's Role in the Prosecutional and Dispositional Stages of the Criminal Justice Process" (paper presented at the Second International Symposium on Victimology, Boston, September 1976); Jack M. Kress, "The Role of the Victim at Sentencing" (paper presented at the Second International Symposium on Victimology, Boston, September 1976).

46. McDonald, pp. 669-73; Kress, pp. 11-15. Kress specifically analyzes restitution as a means for achieving victim involvement.

47. In two types of studies conducted for the Ventura County Board of Supervisors, Ventura, California, support for a restitutional program was indicated: "Both the citizen attitude survey and the Delphi goal-setting exercise revealed a strong concern for the victim as the 'forgotten man' of criminal justice. The Delphi panelists, in particular, emphasized the need for new kinds of criminal penalties in which the offender would be required to make restitution to his victim(s)" (Development of a Model Criminal Justice System [Santa Barbara, Calif.: Public Safety Systems, 1973], p. 85). The report recommends the implementing of a system of restitution. In the two cities mentioned earlier (Columbus and Tucson), support, at least by the parties involved, appeared strong. In the thousands of cases arbitrated by trained law students in Columbus, only 4 percent proceeded further up in the criminal system. In Tucson after one year the program has been successful in all but nine of 204 cases (with the cost of handling each case at $\$ 304$ compared with $\$ 1,566$ required to process the average felony case). General approval of restitution in lieu of punishment was indirectly referred to in the Columbia Law Review's oft-cited study, "Restitution and the Criminal Law": "[E]ven where the complainant can be persuaded to continue the criminal case, after having received private satisfaction, his apathy is often so pronounced and his demeanor so listless that he becomes an extremely weak witness. . . . Also the knowledge of actual restitution seems to greatly assuage the jury. Even the knowledge of the existence of a civil suit can lead the jury to recommend leniency or acquittal" (39 [1939]: 1189; see also n. 31). Restitution, it seems, is accepted and preferred by the average person. Early studies indicate that, when properly administered, even offenders perceive a restitutionary sanction as fair (William Marsella and Burt Galaway, "Study of the Perceived Fairness of Restitution 
This brings us to a second practical objection: that monetary sanctions are insufficient deterrents to crime. Again, this is something to be discovered, not something to be assumed. There are a number of reasons to believe that our current system of punishment does not adequately deter, and for the reasons discussed earlier an increase in the level of punishment is unlikely. In fact, many have argued that the deterrent value of sanctions has less to do with severity than with certainty, ${ }^{48}$ and the preceding considerations indicate that law enforcement would be more certain under a restitutional system. In the final analysis, however, it is irrelevant to argue that more crimes may be committed if our proposal leaves the victim better off. It must be remembered: Our goal is not the suppression of crime; it is doing justice to victims.

A practical consideration which merits considerable future attention is the feasibility of the employment project proposal. A number of questions can be raised. At first blush, it seems naively optimistic to suppose that offenders will be able or willing to work at all, much less earn their keep and pay reparations as well. On the contrary, this argument continues, individuals turn to crime precisely because they lack the skills which the restitutional plan assumes they have. Even if these workers have the skills, but refuse to work, what could be done? Would not the use of force to compel compliance be tantamount to slavery? This criticism results in part from my attempt to sketch an "ideal" restitution system; that is, I have attempted to outline the type toward which every criminal justice system governed by the restitution paradigm should strive. This is not to say that every aspect of the hypothetical system would, upon implementation, function smoothly. Rather, such a system could only operate ideally once the paradigm had been fully accepted and substantially articulated.

With this in mind, one can advance several responses. First, the problem as usually posed assumes the offender to be highly irrational and possibly mentally unbalanced. There is no denying that some segment of the criminal population fits the former description. ${ }^{49}$ What this approach neglects, however, is the possibility that many criminals are making rational choices within an irrational and unjust political system. Specifically I refer to the myriad laws and regulations which make it difficult for the unskilled or persons of transitory outlook ${ }^{\text {so }}$ to find legal employment. ${ }^{\text {s1 }}$ I refer also to

as a Sanction for Juvenile Offenders" [paper presented to the Second International Symposium on Victimology, Boston, September 1976]).

48. Yochelson and Samenow, pp. 453-57.

49. For a discussion rejecting the usefulness of the latter description, see Szasz, pp. 91-146; for a recent study verifying Szasz's thesis, see Yochelson and Samenow, esp. pp. 227-35.

50. Edward C. Banfield put forth his controversial theory of time horizon in his book The Unheavenly City (Boston: Little, Brown \& Co., 1970) and amplified it in The Unheavenly City Revisited (Boston: Little, Brown \& Co., 1974), and most recently, "Present-orientedness and Crime" (paper prepared for the Symposium on Crime and Punishment: Restitution, Retribution, and Law, Harvard Law School, March 1977). For a critical, but favorable analysis of this approach, see Gerald P. O'Driscoll, Jr., "Professor Banfield on Time Horizon: What Has He Taught Us about Crime?" 
the laws which deny legality to the types of services which are in particular demand in economically impoverished communities. ${ }^{52}$ Is it "irrational" to choose to steal or rob when one is virtually foreclosed from the legal opportunity to do otherwise? Another possibility is that the criminal chooses crime not because of foreclosure, but because he enjoys and obtains satisfaction from a criminal way of life. ${ }^{53}$ Though morally repugnant, this is hardly irrational.

Furthermore, it no longer can be denied that contact with the current criminal justice system is itself especially damaging among juveniles. ${ }^{54}$ The offenders who are hopelessly committed to criminal behavior are not usually the newcomers to crime but those who have had repeated exposure to the penal system. In Kuhn's words, "Existing institutions have ceased to meet the problems posed by an environment they have in part created." Ws While a restitutionary system might not change these hard-core offenders, it could, by the early implementation of sanctions perceived by the criminal to be just, break the vicious circle which in large part accounts for their existence.

Finally, if offenders could not or would not make restitution, then the logical and just result of their refusal would be confinement until they could or would. Such an outcome would be entirely in their hands. While this "solution" does not suggest who should justly pay for this confinement, the problem is not unique to a restitutionary system. In this and other areas of possible difficulty we must seek guidance from existing pilot programs as well as from the burgeoning research in this area and in victimology in general.

2. Distributionary criticisms of restitution. There remains one criticism of restitution which is the most obvious and the most difficult with which to deal. Simply stated, it takes the following form: "Doesn't this mean that rich people will be able to commit crimes with impunity if they can afford it? Isn't this unfair?" The practical aspect of this objection is that whatever deterrent effect restitution payments may have, they will be less for those most able to pay. The moral aspect is that whatever retributive or penal

(paper prepared for the same symposium). A contrary, but ultimately compatible view is presented by Yochelson and Samenow, pp. 369-72.

51. For example, minimum wage laws, and so-called closed-shop union protectionist legislation.

52. For example, laws prohibiting gambling, prostitution, sale of drugs, "jitney" cab services, etc.

53. "It is not the environment that turns a man into a criminal. Rather it is a series of choices that he makes at a very early age. . . . [T] The criminal is not a victim of circumstances" (Yochelson and Samenow, pp. 247, 249). This is in essence the main conclusion of their research. (For a concise summary of their provocative book, see Joseph Boorkin, "The Criminal Personality," Federal Bar Journal 35 [1976]: 237-41.) In The Criminal Personality, vol. 2, The Process of Change (New York: Jason Aronson, Inc., 1977) they relate and examine the methods they have employed to change the criminal thought pattern. Of course, such an approach can itself be subject to abuse.

54. See, e.g., Edwin M. Schur, Radical Noninterventionism, Rethinking the Delinquency Problem (Englewood Cliffs, N.J.: Prentice-Hall, Inc., 1973).

55. Kuhn, p. 92 (emphasis added). 
effect restitution payments may have they will be less for those who are well off. Some concept of equality of justice underlies both considerations.

Critics of restitution fail to realize that the "cost" of crime will be quite high. In addition to compensation for pain and suffering, the criminal must pay for the cost of his apprehension, the cost of the trial, and the legal expenditures of both sides. This should make even an unscrupulous wealthy person think twice about committing a crime. The response to this is that we cannot have it both ways. If the fines would be high enough to bother the rich, then they would be so high that a project worker would have no chance of earning that much and would, therefore, have no incentive to work at all. If, on the other hand, you lower the price of crime by ignoring all its costs, you fail to deter the rich or fully compensate the victim.

This is where the option of arbitration and victim crime insurance becomes of practical importance. If the victim is uninsured, he is unlikely to recover for all costs of a very severe crime from a poor, unskilled criminal, since even in an employment project the criminal might be unable to earn enough. If he had no hope of earning his release, he would have little incentive to work very hard beyond paying for his own maintenance. The victim would end up with less than if he had "settled" the case for the lesser amount which a project worker could reasonably be expected to earn. If, however, the victim had full-coverage criminal insurance, he would recover his damages in full, and the insurance company would absorb any disparity between full compensation and maximal employment project worker's output. This cost would be reflected in premium prices, enabling the insurance company which settled cases at an amount which increased the recovery from the criminal to offer the lowest rates. Eventually a "maximum" feasible fine for project workers would be determined based on these considerations. The "rich," on' the other hand, would naturally have to pay in full. This arrangement would solve the practical problem, but it should not be thought of as an imperative of the restitutional paradigm.

The same procedure of varying the payments according to ability to pay would answer the moral considerations as well (that the rich are not hurt enough) and this is the prime motive behind punitive restitution proposals. However, we reject the moral consideration outright. The paradigm of restitution calls not for the (equal) hurting of criminals, but for restitution to victims. Any appeal to "inadequate suffering" is a reversion to the paradigm of punishment, and by varying the sanction for crimes of the same magnitude according to the economic status of the offender it reveals its own inequity. Equality of justice means equal treatment of victims. It should not matter to the victim if his attacker was rich or poor. His plight is the same regardless. Any reduction of criminal liability because of reduced earning power would be for practical, not moral, reasons.

Equality of justice derives from the fact that the rights of men should be equally enforced and respected. Restitution recognizes a victim's right to 
compensation for damages from the party responsible. Equality of justice, therefore, calls for equal enforcement of each victim's right to restitution. Even if necessary or expedient, any lessening of payment to the victim because of the qualities of the criminal is a violation of that victim's rights and an inequality of justice. Any such expedient settlement is only a recognition that an imperfect world may make possible only imperfect justice. As a practical matter, a restitutional standard gives victims an enormous incentive to pursue wealthy criminals since they can afford quick, full compensation. Contrast this with the present system where the preference given the wealthy is so prevalent that most victims simply assume that nothing will be done.

The paradigm of restitution, to reiterate, is neither a panacea for crime nor a blueprint for utopia. Panaceas and utopias are not for humankind. We must live in a less than perfect world with less than perfect people. Restitution opens the possibility of an improved and more just society. The old paradigm of punishment, even reformed, simply cannot offer this promise.

\section{OTHER CONSIDERATIONS}

Space does not permit a full examination of other less fundamental implications of such a system. I shall briefly consider five.

1. Civil versus criminal liability. If one accepts a restitutionary standard of justice, what sense does it make to distinguish between crime and tort, since both call for payment of damages? For most purposes I think the distinction collapses. Richard Epstein, in a series of brilliant articles, has articulated a theory of strict liability in tort. ${ }^{56}$ His view is that since one party has caused another some harm and one of the parties must bear the loss, justice demands that it falls on the party who caused the harm. He argues that intention is only relevant as a "third-stage" argument; that notwithstanding some fault on the part of the plaintiff (a second-stage argument), the defendant intended the harm and is therefore liable. ${ }^{57}$ With a restitutional system I see no reason why Epstein's theory of tort liability could not incorporate criminal liability into a single "system of corrective justice that looks to the conduct, broadly defined, of the parties to the case with a view toward the protection of individual liberty and private property." ${ }^{38}$

56. Richard A. Epstein, "A Theory of Strict Liability in Tort," Journal of Legal Studies 2 (1973): 151-204.

57. Richard A. Epstein, "Intentional Harms," Journal of Legal Studies 3 (1975): 402-8; see also his article "Defenses and Subsequent Pleas in a System of Strict Liability," ibid., 3 (1974): 174-85.

58. Epstein, "Intentional Harms," p. 441. Epstein himself would disagree. In a recent article, also notable for its well-reasoned rejection of victim compensation/welfare schemes, "Crime and Tort: Old Wine in Old Bottles" (paper prepared for the Symposium on Crime and Punishment: Restitution, Retribution and Law, Harvard Law School, March 1977), he draws an emphatic distinction between tort and criminal law. He rests this distinction on two characteristics of the criminal law: (a) that its function is to punish (and therefore mens rea is required and more stringent procedural safeguards are appropriate), and $(b)$ since the defendant is prosecuted by the state, fairness as between the parties is not relevant. From these assumptions, Epstein reasons quite correctly that 
There would, at least initially, be some differences, however. The calculation of damages under the restitutionary paradigm which includes cost of apprehension, cost of trial, and legal costs of both parties would be higher than tort law allows. A further distinction would be the power of enforcers to confine unreliable offenders to employment projects. ${ }^{99}$

2. Criminal responsibility and competency. Once a criminal sanction is based not on the offender's badness but on the nature and consequences of his acts, Thomas Szasz's proposal that the insanity plea be abolished makes a great deal of sense, ${ }^{60}$ as does his argument that "all persons charged with offenses-except those grossly disabled-[are fit to stand trial and] should be tried." ${ }^{\prime 1}$ On this view, Epstein's concept of fairness as between the parties is relevant. A restitution proceeding like a "lawsuit is always a comparative affair. The defendant's victory ensures the plaintiff's [or victim's] defeat. ... Why should we prefer the injurer to his victim in a case where one may win and the other lose?... As a matter of fairness between the parties, the defendant should be required to treat the harms which he has inflicted upon another as though they were inflicted upon himself."

3. Victimless crimes. The effect of restitutional standards on the legality of such crimes as prostitution, gambling, high interest loans, pornography, and drug use is intriguing. There has been no violation of individual rights, and consequently no damages and, therefore, no liability. While some may see this as a drawback, I believe it is a striking advantage of the restitutional standard of justice. So-called victimless crimes would in principle cease to be crimes. As a consequence, criminal elements would be denied a lucrative monopoly, and the price of these services would be

the two systems are inherently different. It should be obvious that a restitutionary paradigm undermines both assumptions. Gilbert M. Cantor in his article, "An End to Crime and Punishment" (Shingle 39 [May 1976]: 99-114), takes precisely this view, arguing that "the time has come to abolish the game of crime and punishment and to substitute a paradigm of restitution and responsibility. I urge that we assign (reassign, actually) to the civil law our societal response to the acts or behaviors we now label and treat as criminal. The goal is the civilization of our treatment of offenders. I use the word, 'civilization' here in its specific meaning: to bring offenders under the civil, rather than the criminal law; and in its larger meaning: to move in this area of endeavor from barbarism toward greater enlightenment and humanity" (p. 107; emphasis in original).

59. It would seem that the only way to account for these differences would be an appeal to the mens rea or badness of the criminal as opposed to the unintentional tortfeasor. Yet such an approach, it might be argued, is not available to a restitutionary system which considers the moral outlook of an offender to be irrelevant to the determination of the proper criminal sanction. A possible response is that this overstates the restitutionist claim. That a criminal's mental state does not justify punishment does not imply that it is not relevant to any aspect of the criminal justice process. It may well be that it is relevant to the consideration of methods by which one is justified in extracting what, on other grounds, is shown to be a proper sanction, that is, restitution.

60. Szasz, pp. 228-30.

61. Ibid., pp. 228-29. "The emphasis here is on gross disability: it should be readily apparent or easily explicable to a group of lay persons, like a jury" (p. 229). But even the qualification of gross disablement might be unjustified (see Yochelson and Samenow, pp. 227-35).

62. Epstein, p. 398. In his article "Crime and Tort: Old Wine in Old Bottles," he takes exactly this approach with the insanity defense in tort law. 
drastically reduced. Without this enormous income, organized crime would be far less able to afford the "cost" of its nefarious activities than it is today.

4. Legal positivism. What is true for victimless crimes is true for the philosophy of legal positivism. On the positivist view, whatever the state (following all the correct political procedures) says is law, is law; hence, whatever the state makes a crime is a crime. A restitutional standard would hold the state to enforcing individual rights through the recovery of individual damages.

5. Legal process. Because the sanction for crime would no longer be punitive, the criminal process could explore less formal procedures for dispute settlement. Also, the voice of the victim would be added to the deliberations. One possible reform might be a three-tiered verdict: guilty, not proven, and not guilty. If found "guilty," the offender would pay all the costs mentioned above. If the charges are "not proven," then neither party would pay the other. If found "not guilty," the defendant would be reimbursed by the enforcement agency for his costs and inconvenience. This new interpretation of "not guilty" would reward those defendants who, after putting on a defense, convinced the trier of fact that they were innocent.

These and many other fascinating implications of restitution deserve a more thorough examination. As any new paradigm becomes accepted, it experiences what Kuhn calls a period of "normal research," a period characterized by continuous expansion and perfection of the new paradigm as well as a testing of its limits. The experimentation with restitutionary justice will, however, differ from the trial and error of the recent past since we will be guided by the principle that the purpose of our legal system is not to harm the guilty but to help the innocent - a principle which will above all restore our belief that our overriding commitment is to do justice. 